УДК 616-089.8+617

DOI 10.11603/2414-4533.2016.3.6797

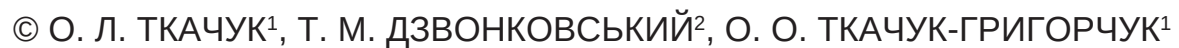

ДВНЗ “Івано-Франківський національний медичний університет"1

Івано-Франківська обласна клінічна лікарня

\title{
Досвід застосування малоінвазивних втручань в ургентній хірургії
}

\author{
O. L. TKACHUK ${ }^{1}$, T. M. DZVONKOVSKYI², O. O. TKACHUK-HRYHORCHUK ${ }^{1}$
}

Ivano-Frankivsk National Medical University ${ }^{1}$

Ivano-Frankivsk Regional Clinical Hospital ${ }^{2}$

\section{EXPERIENCE OF MINIMALLY INVASIVE INTERVENTIONS IN EMERGENCY SURGERY}

\begin{abstract}
На підставі аналізу статистичних показників роботи клініки наведено характеристику досвіду застосування малоінвазивних технологій в ургентній хірургії. Автори описали варіанти хірургічної тактики при різних гострих хірургічних захворюваннях. Обгрунтовано необхідність організаційних нововведень, а також підготовки фахівців. Зроблено висновок про необхідність розширення застосування малоінвазивних втручань в ургентній хірургії.

On the basis of statistical indicators of the clinic work there is given a characteristics of experience of minimally invasive technologies in emergency surgery. The authors describe the surgical treatment options for various acute surgical diseases. It was indicated the necessity of organizational innovations and training. The conclusion about the need to expand the application of minimally invasive interventions in emergency surgery.
\end{abstract}

Постановка проблеми і аналіз останніх досліджень та публікацій. Малоінвазивні втручання на даний час посідають одне з головних місць не тільки в плановій хірургії, а й в ургентній. Основними перевагами лапароскопії над втручаннями, що виконуються лапаротомним доступом, $є$ низька травматичність, скорочення термінів лікування, косметичний ефект для хворого і кращі операційні можливості для хірурга. Протягом останнього десятиріччя в Україні зростає кількість лапароскопічних операцій як у лікувальних закладах третинного рівня, так і в районних та міських лікарнях. 3окрема, в Івано-Франківській області на даний час функціонують 23 лапароскопічні стійки у 12 лікувальних закладах міст та районних центрів.

Зросла кількість хірургів, які оволоділи лапароскопічними технологіями. Так, за останні 3 роки на базі кафедри хірургії ПО ІФНМУ на курсах тематичного удосконалення “Лапароскопічні хірургічні втручання” підготовлено понад 50 спеціалістів. Частина хірургів-лапароскопістів навчалася на базі Тернопільського центру підготовки, на базі Київських центрів та за кордоном, зокрема у центрі IRCAD у Страсбурзі (Франція).

Якщо на початку формування лапароскопічної галузі хірургічної служби організація роботи спрямовувалась на створення окремих відділень малоінвазивної хірургії, наприклад в Івано-Фран- ківській ОКЛ і центральній міській клінічній лікарні, у Калуській центральній районній лікарні, то в останні роки відмічено тенденцію до формування лапароскопічного напрямку в загальнохірургічних відділеннях. Це вимагає певних організаційних та управлінських рішень, зокрема налагодження ургентних чергувань серед хірургів-лапароскопістів, підготовки всіх ургентних хірургів до проведення лапароскопічних операцій, організації цілодобового доступу до лапароскопічного обладнання та інструментарію. 3 часом лапароскоп стає одним із рутинних інструментів у арсеналі кожного абдомінального хірурга.

Мета роботи: оцінити ефективність та доцільність широкого застосування лапароскопії в роботі ургентного хірурга на підставі аналізу роботи хірургічної клініки Івано-Франківської ОКЛ.

Матеріали і методи. Проведено статистичний та описовий аналіз застосування лапароскопічних втручань при ургентних хірургічних захворюваннях у відділеннях хірургічного профілю Івано-Франківської ОКЛ за 5 років. Аналіз виконано шляхом тотальної вибірки даних із системи комп’ютеризованого обліку “УКР МЕДСОФТ 4” компанії Медіасофт, а також шляхом вивчення статистичних звітів відділення хірургії та центру малоінвазивної хірургії. 
Результати досліджень та їх обговорення. За період з 2011 до 2015 р. в Івано-Франківській обласній клінічній лікарні проведено 2058 ургентних хірургічних операцій на органах черевної порожнини. 3 них 964 операції проведено із застосуванням малоінвазивних технологій, зокрема 10 У3-контрольованих пункційних втручань, 242 трансдуоденальні ендоскопічні операції та 712 лапароскопічних операцій. Таким чином, частка лапароскопічних операцій в ургентній хірургії черевної порожнини склала за 5 років 34,6 \%. Динаміка кількості операцій (табл. 1) свідчить про ріст як абсолютної кількості ургентних втручань, так і певне зростання відносної частки лапароскопічних операцій.

Водночас слід відзначити, що стрімкий ріст кількості лапароскопій у 2011-2013 pр. змінився стабільною динамікою впродовж останніх двох років.

Аналіз структури ургентних лапароскопічних втручань (табл. 2) вказує на значну кількісну перевагу холецистектомій.

Частка лапаротомних холецистектомій при гострому холециститі серед загальної кількості холецистектомії у хірургічних відділеннях лікарні складає лише 0,95 \%. Конверсії у лапаротомію при ЛХЕ виконували в 0,91 \% випадків. Запланована холецистектомія лапаротомним доступом застосовується в клініці лише за наявності холедохолітіазу, який не вдалося усунути шляхом ЕРХПГ. За нашим досвідом, навіть у такому випадку більш якісною $є$ лапароскопічна холецистектомія із запланованою конверсією для холедохолітоекстракції.

Холедохолітіаз відповідно до діючого клінічного протоколу, затвердженого МО3 України у 2010 р., потребує лапаротомного доступу. Однак наявність у клініці розвинутої ендоскопічної хірургічної служби, високий рівень підготовки фахівців дозволяють нам у більшості випадків (понад 80 \%) успішно застосовувати двохетапну ма- лоінвазивну тактику, яка передбачає проведення ЕРХПГ з папілотомією та літоекстракцією на першому етапі та ЛХЕ - на другому. Досвід показує, що оптимальним $є$ проведення другого етапу на наступний день, коли зменшується пневматизація кишечника, відсутні симптоми ускладнень, які можуть потребувати зміни хірургічної тактики.

За 5 років у клініці проведено 2064 трансдуоденальних папілосфінктеротомій, серед них з приводу холедохолітіазу - 611, у тому числі 236 в ургентному порядку.

Невдала ендоскопічна холедохолітоекстракція потребує вибору альтернативного варіанта хірургічного доступу. Серед них заслуговує уваги лапароскопічна холедохолітоекстракція. У клініці проведено 12 таких операцій, з них 6 із застосуванням холедохоскопа, 5 - 3 мануальною асистенцією через міні-лапаротомію. Операцію завершували дренуванням холедоха за Кером або у частині випадків - глухим швом холедоха, враховуючи попередньо проведену папілотомію.

При невдалій спробі ЕРПХГ через незручний доступ до фатерового сосочка, наявність перипапілярного дивертикула, стенозу папіли варіантом хірургічної тактики є спроба антеградного канюлювання холедоха лапароскопічним шляхом. Протягом останнього року проведено 6 таких операцій. Виконуємо лапароскопічну холецистектомію з проведенням катетера в міхурову протоку на максимальну глибину. Використовуємо катетер 6-8 Fr для підключичної вени. Катетер фіксуємо в куксі міхурової протоки ендопетлею. Після видалення жовчного міхура хворого переводять у рентгенопераційну, де під рентгенівським та ендоскопічним контролем антеградно контрастують холедох, при необхідності вводять у катетер провідник, по якому ретроградно проникають у холедох папілотомом, кошиком Дорміа, балонним дилататором та ін-

Таблиця 1. Динаміка кількості ургентних лапароскопічних операцій

\begin{tabular}{||l|c|c|c|c|c||}
\hline Кількість лапароскопічних операцій & 2011 & 2012 & 2013 & 2014 & 2015 \\
\hline Абс. & 47 & 127 & 261 & 228 & 243 \\
\hline$\%$ & 15,2 & 28 & 45 & 46,5 & 46,3 \\
\hline
\end{tabular}

Таблиця 2. Структура ургентних лапароскопічних втручань за 5 років

\begin{tabular}{|l|c|c|}
\hline \multicolumn{1}{|c|}{ Назва операції } & Кількість & \% \\
\hline Лапароскопічна холецистектомія & 517 & 72,6 \\
\hline Лапароскопічна апендектомія & 59 & 8,3 \\
\hline Діагностична лапароскопія & 57 & 8,0 \\
\hline Лапароскопічне дренування черевної порожнини & 43 & 6,0 \\
\hline Лапароскопічне роз’дднння злук & 10 & 1,4 \\
\hline Ургентна гінекологічна патологія & 10 & 1,4 \\
\hline Зашивання перфоративної виразки & 5 & 0,7 \\
\hline Лапароскопічна холедохолітоекстракція & 5 & 0,7 \\
\hline Інші & 6 & 0,8 \\
\hline
\end{tabular}


шими необхідними інструментами. В усіх 6 випадках вдалося видалити конкременти без лапаротомії.

Другою за кількістю операцій є лапароскопічна апендектомія (ЛА). На нашу думку, цю операцію слід вважати “золотим стандартом” поряд 3 холецистектомією. Запровадження ЛА дозволяє уникнути як помилкової гіпердіагностики гострого апендициту, так і несвоєчасного встановлення діагнозу. На діагностичному етапі лапароскопія дозволяє виявити більшість захворювань, які симулюють картину гострого апендициту. Вдається діагностувати низку захворювань, які не мають патогномонічної клінічної симптоматики, зокрема каловий камінь апендикса, перекрут жирової підвіски, мікроперфорацію кишечника стороннім тілом, ішемічний абдомінальний синдром та ін. Широке рутинне застосування ЛА стримується лише тим, що не всі ургентні хірурги володіють цією операцією і не завжди є організаційна можливість налагодження цілодобового доступу до лапароскопічної операційної. У нашій клініці, як і в хірургічних стаціонарах міських лікарень Івано-Франківська та у кількох районних лікарнях, адміністрація організувала можливість таких операцій. Кафедра хірургії післядипломної освіти активно готує хірургів області до проведення ЛА.

Незаперечні переваги лапароскопії в діагностиці гострої абдомінальної хірургічної патології. У 2013 р. Американська хірургічна асоціація (ASA) запропонувала нову клінічну настанову “Діагностична лапароскопія”. Настанова містить доказові рекомендації щодо показань, техніки проведення та алгоритмів тактики при різних ситуаціях як ургентної, так і планової хірургії. Ми підготували презентацію на основі даної настанови. Діагностика гострої хірургічної патології шляхом лапароскопії $\epsilon$ кінцевим діагностичним засобом, який не лише допомагає завершити діагностичний процес, уникнути діагностичної помилки, але часто і провести лікувальне втручання й усунути патологічну проблему.

Класична хірургічна діагностична програма включає в себе лапароцентез як спосіб отримати та оцінити перитонеальний ексудат. Приліжкова лапароскопія в умовах відділення інтенсивної терапії, особливо у хворих, які перебувають у коматозному стані, на ШВЛ, часто є сучасною ефективною альтернативою лапароцентезу, дозволяючи виключити або підтвердити наявність хірургічної проблеми у черевній порожнині. Для виконання маніпуляції не потрібна лапароскопічна стійка. Інсуфляцію можна провести киснем чи повітрям, достатньо одного троакара, лапароскопа та освітлювача. Огляд можна здійснити безпосередньо через окуляр лапароскопа без застосування відеокамери та монітора.

Діагностика травми живота шляхом лапароскопії дозволяє уникнути даремної лапаротомії, на- приклад при проникаючому пораненні живота без ушкодження внутрішніх органів. Поверхневі розриви капсули печінки, субсерозні крововиливи, заочеревинні гематоми можуть бути успішно діагностовані, локалізовані та сановані лапароскопічним шляхом. Лапароскопічна спленектомія при розриві селезінки допустима, на нашу думку, лише в окремих випадках, при наявності досвіду подібних операцій у членів операційної бригади. Конверсія в лапаротомію в такій ситуації є виправданою.

Дискусійним є питання показань до проведення лапароскопії при гострій кишковій непрохідності. Роздуті петлі кишечника створюють ризик троакарного ушкодження. Однак при дотриманні безпечних технік введення першого троакара ятрогенних ушкоджень вдається уникнути. Вибір хірургічного доступу - лапароскопічного чи лапаротомного - повинен проводитися індивідуально у кожному випадку, враховуючи наявність та ступінь пневматизації кишечника, компартмент-синдрому, прогнозоване вираження злукового процесу. Тотальний адгезивно-злуковий процес вимагає конверсії в лапаротомію, однак поодинокі злуки та зрощення переважно вдається усунути лапароскопічним шляхом. Тактику лапароскопічного ведення злукової хвороби описано в публікаціях наших колег із Тернопільської лапароскопічної школи [1]. Для профілактики повторного злукоутворення необхідно провести аплікацію місцевоактивних протизлукових препаратів.

Відносно новим лапароскопічним втручанням, освоєним останніми роками у клініці, є зашивання перфоративної виразки. Успішною є лапароскопічна тактика при гострій виразці на передній стінці цибулини дванадцятипалої кишки чи шлунка. Хронічну кальозну виразку з деформацією та стенозом виходу зі шлунка розглядаємо як показання до конверсії.

Важливим розділом ургентної абдомінальної хірургії $є$ вибір тактики ведення хворих на гострий панкреатит. В історії даного питання спостерігається тенденція до обмеження та відтермінування хірургічних втручань, пріоритет консервативного ведення хворих. Згідно з проектом нового клінічного протоколу ведення гострого панкреатиту, який винесений на громадське обговорення на сайті МO3 України, у фазі асептичного панкреонекрозу показання до хірургічного лікування виникають лише при гострому панкреатиті біліарної етіології. При наявності холангіту слід провести ЕРПХГ з літоекстракцією, а при наявності гострого холециститу лапароскопічну холецистектомію. Ми маємо багаторічний досвід лапароскопічного дренування черевної порожнини при наявності ферментативного перитоніту. Вважаємо, що недоцільно намагатися дренувати сальникову сумку та перипанкреатичну заочеревинну клітковину, оскільки, крім інфікуван- 
ня, це не дає жодного позитивного результату. Достатньо евакуювати ексудат та розмістити в черевній порожнині 2-3 трубчастих дренажі на 2-3 доби. Слід зауважити, що лапароскопічне дренування при гострому панкреатиті в американських та європейських клінічних протоколах не розглядається як самостійне хірургічне втручання. При біліарному панкреатиті таке дренування $є$ доповненням до холецистектомії, а при аліментарному (алкогольному) панкреатиті - це фактично завершення діагностичної лапароскопії.

Друга фаза гострого панкреатиту - секвестрація залози, формування панкреатичних і перипанкреатичних абсцесів та кіст - також зумовлює показання до малоінвазивних технологій дренування. Ми застосовуємо УЗ-контрольовані пункції гнояків, встановлення катетера типу “pig tail” з наступним дренуванням переважно заочеревинним доступом шляхом люмботомії.

Новим напрямком хірургії панкреонекрозу у фазі гнійних ускладнень є ендоскопічні дренуючі втручання. Протягом останніх двох років проведено 16 транслюмінальних ендоскопічних дренувань абсцесів та кіст підшлункової залози. Рідинні скупчення, які прилягають до стінки дванадцятипалої кишки чи шлунка, розкривали голчастим папілотомом, що дозволяло евакуювати вміст у просвіт шлунково-кишкового тракту. Щоб запобігти передчасному закриттю нориці, останню розширювали струнним папілотомом або стентували пластиковим стентом максимально можливого діаметра (до 12 Fr). У 8 випадках вдалося уникнути лапаротомних операцій. В інших випадках транслюмінальне дренування було лише етапом лікування панкреонекрозу перед наступним розширеним дренуванням. Така ступінчаста тактика лікування панкреонекрозу рекомендується сучасними клінічними настановами на підставі доказових рандомізованих досліджень та метааналізів.

Діагностичні лапароскопії при підозрі на гострий живіт часто дозволяють виявити гостру гінекологічну патологію, яка в більшості випадків може бути усунута лапароскопічним шляхом. Залучення гінеколога до складу операційної бригади є бажаним, але не завжди реальним шляхом в умовах загальнохірургічного відділення. Більшість наших лапароскопічних хірургів володіють технікою сальпінготомії та сальпінгектомії при позаматковій вагітності, технікою коагуляційного

\section{СПИСОК ЛІТЕРАТУРИ}

1. Дзюбановський I. Я. Динамічний лапароскопічний адгезіолізис в лікуванні спайкової хвороби очеревини / I. Я. Дзюбановський, О. Г. Дикий // Шпитальна хірургія. 2006. - № 3. - С. 33-37. гемостазу та резекції яєчника при апоплексії, а також технікою видалення кіст яєчників. При виявленні пельвіоперитоніту, пухлинних захворювань рішення про подальшу тактику приймається консиліумом з участю гінеколога.

Актуальною в ургентній хірургії є профілактика венозних тромбоемболічних ускладнень, враховуючи зміни реології у хворих, порушення гемокоагуляції при гострих хірургічних захворюваннях, а також з огляду на вплив пневмоперитонеуму на венозне повернення крові в системі нижньої порожнистої вени.

Вважаємо, що профілактику тромботичних ускладнень треба проводити диференційовано. Індивідуальний підбір профілактичних засобів, включаючи ранню активізацію хворих після операції, механічні засоби, такі як еластичне бинтування та пневмокомпресія нижніх кінцівок, слід застосовувати з урахуванням індексу тромботичного ризику за Caprini [2].

Таким чином, лапароскопічні та трансдуоденальні ендоскопічні операції займають все більше місце у тактиці ведення ургентної абдомінальної хірургічної патології.

Важливим кроком удосконалення ефективності роботи відділення малоінвазивної хірургії є дообладнання лапароскопічної стійки і налагодження онлайнової відеотрансляції операцій. Встановлення відносно недорогого відеореєстратора та підключення до мережі лікарні дозволяє не лише задовольнити потреби педагогічного процесу - навчання інтернів та курсантів, але й залучити колектив відділення до прийняття рішень у складних випадках. Кожен хірург відділення має можливість спостерігати на своєму моніторі хід операції, збагачувати свій досвід або надавати свої рекомендації операційній бригаді.

Висновки. 1. Понад 40 \% хворих з ургентними захворюваннями органів черевної порожнини підлягають лапароскопічним хірургічним втручанням.

2. Діапазон лапароскопічних операцій має тенденцію до розширення, включаючи в себе як діагностичні, так і лікувальні втручання.

3. Хворі з ургентною хірургічною патологією органів черевної порожнини потребують індивідуалізованого вибору хірургічної тактики з урахуванням наявності у клініці лапароскопічного обладнання, інструментарію та підготовлених спеціалістів.

2. Caprini J. A. The influence of oral anticoagulation therapy on deep vein thrombosis rates four weeks after total hip replacement / J. A. Caprini J. I. Arcelus, G. Motykie [et al.] // Vase Surg. - 1999. - Vol. 30. - P. 813-820. 